\title{
LncRNA-ENST00000421645 Upregulates Kank1 to Inhibit IFN- $\gamma$ Expression and Promote T Cell Apoptosis in Neurosyphilis
}

\author{
Kai-Xuan Wu ${ }^{1+}$, Xiao-Tong Wang ${ }^{1 \dagger}$, Xin-Lin $\mathrm{Hu}^{2 \dagger}$, Xiao-Yong Jiang ${ }^{2 \dagger}$, Jing-Cong Zhuang ${ }^{3}$, \\ Yan-Zhu Xu' ${ }^{2}$, Li-Rong Lin', Man-Li Tong ${ }^{1}$, Tian-Ci Yang ${ }^{1}$ and Li-Li Liu ${ }^{1 *}$ \\ ${ }^{1}$ Center of Clinical Laboratory, School of Medical, Zhongshan Hospital, Xiamen University, Xiamen, China, ${ }^{2}$ Department \\ of Dermatology, School of Medical, Zhongshan Hospital, Xiamen University, Xiamen, China, ${ }^{3}$ Department of Neurology, \\ School of Medical, Zhongshan Hospital, Xiamen University, Xiamen, China
}

OPEN ACCESS

Edited by:

Michal Letek,

Universidad de León, Spain

Reviewed by:

Catherine Ayn Brissette,

University of North Dakota,

United States

Raul Miranda-CasoLuengo,

University College Dublin, Ireland

*Correspondence:

Li-Li Liu

liulili@xmu.edu.cn

${ }^{\dagger}$ These authors have contributed equally to this work

Specialty section:

This article was submitted to Infectious Agents and Disease,

a section of the journal

Frontiers in Microbiology

Received: 29 August 2021 Accepted: 10 November 2021 Published: 30 November 2021

Citation:

Wu K-X, Wang $X-T$, Hu X-L, Jiang $X-Y$, Zhuang J-C, $X U$ Y-Z, Lin L-R, Tong M-L, Yang T-C and Liu L-L (2021)

LnCRNA-ENST00000421645 Upregulates Kank1 to Inhibit IFN- $\gamma$ Expression and Promote T Cell

Apoptosis in Neurosyphilis.

Front. Microbiol. 12:749171. doi: 10.3389/fmicb.2021.749171
Long non-coding RNAs are involved in many infectious diseases. Our previous studies showed that InCRNA-ENST00000421645 expression is increased in T lymphocytes of neurosyphilis patients compared to healthy controls. However, whether IncRNAENST00000421645 has biological functions remains unclear. The current study was undertaken to understand the mechanism of IncRNA-ENST00000421645 in $\mathrm{T}$ lymphocyte function in neurosyphilis patients. The IncRNA-ENST00000421645 pull-down assay showed that IncRNA-ENST00000421645 acted on the acetylase NAT10. The chromatin immunoprecipitation (ChIP)-PCR results showed that IncRNAENST00000421645 promoted the acetylation of histone H3K27 adjacent to the Kank1 promoter, thereby promoting Kank1 protein expression. Kank1 promotes 14-3-3 protein expression, inhibits NF-kB activation, inhibits IFN- $\gamma$ secretion by T lymphocytes, and promotes $T$ lymphocyte apoptosis. Taken together, our findings suggest a novel mechanism that LncRNA-ENST00000421645 upregulates Kank1 to inhibit IFN- $\gamma$ expression and promote T cell apoptosis in neurosyphilis.

Keywords: LncRNA-ENST00000421645, IFN- $\gamma$ expression, T cell apoptosis, neurosyphilis, Kank1, 14-3-3

\section{INTRODUCTION}

Neurosyphilis is a central nervous system disease caused by Treponema pallidum (TP). It is one of the most destructive and difficult clinical types of syphilis (Gonzalez et al., 2019). The mechanism of $T P$-induced neurosyphilis is not fully understood. In our previous experiments, we found an abnormal humoral immune response and cellular immune response in neurosyphilis patients (Liu et al., 2013). Assessment of cerebrospinal fluid (CSF) abnormalities in neurosyphilis patients without human immunodeficiency virus (HIV) infection indicated that $\mathrm{CD} 3^{+} \mathrm{CD} 4^{+} \mathrm{T}$ cells play a dominant role in the CSF of neurosyphilis patients (Leader et al., 2007; Li et al., 2013). The number of $\mathrm{CD}^{+} \mathrm{T}$ cells in the CSF of asymptomatic neurosyphilis patients and neurosyphilis patients with brain parenchymal injury was significantly higher than that in the CSF of syphilis patients without nerve injury (Leader et al., 2007). Marra et al. (1998) established a model of TP invasion into the nervous system and found that the $\mathrm{T}$ lymphocytes in the CSF were mainly $\mathrm{CD} 4^{+} \mathrm{T}$ cells, suggesting that $\mathrm{T}$ helper (Th) cells may be recruited into the nervous system to clear TP. 
Accumulating evidence shows that lncRNA mediate the regulation of host $\mathrm{CD} 4^{+} \mathrm{T}$ cells and macrophages to participate in the host cell response to microbial infections (Yin et al., 2013; Y1lmaz Susluer et al., 2018). For example, after Toxoplasma gondii infection, non-shat022487 inhibits IL-12, tumor necrosis factor- $\alpha$ (TNF- $\alpha)$ and IFN- $\gamma$ expression by downregulating the expression of the immune-activating molecule unc93b1 in human macrophages (Liu et al., 2018), contributing to the establishment of chronic Toxoplasma infection. In staphylococcal enterotoxin $\mathrm{B}$-activated $\mathrm{CD} 4{ }^{+} \mathrm{T}$ cells of $\mathrm{C} 57 \mathrm{BL} / 6 \mathrm{~J}$ mice, the long non-coding RNA (lncRNA) AW112010 inhibits IL-10 expression through histone demethylation and promotes the differentiation of inflammatory $\mathrm{T}$ cells (Yang et al., 2020). During Mycobacterium tuberculosis infection, IncRNA-CD244 directly interacts with the polycomb repressive complexes(PRC2) subunit enhancer of zeste homolog 2(EZH2), which leads to histone H3 lysine (K) 27 methylation and confers a stronger inhibitory chromatin state at IFN- $\gamma$ or TNF- $\alpha$ loci (Wang et al., 2015). In other words, $\ln c R N A-C D 244$ upregulates the $\mathrm{T}$ cell suppressor CD244 to inhibit the expression of TNF$\alpha$ and IFN- $\gamma$. TNF- $\alpha$ expression through lncRNA may be a new mechanism of $M$. tuberculosis infection. In our previous study, the changes in the lncRNA expression profiles of $\mathrm{CD} 4^{+} \mathrm{T}$ lymphocytes in neurosyphilis patients and healthy controls were analyzed using a non-coding RNA microarray platform. Different lncRNA and mRNA expression profiles were found. Specifically, in the neurosyphilis group, 393 lncRNAs were significantly upregulated, 287 lncRNAs were significantly downregulated, 287 mRNAs were significantly upregulated, and 331 mRNAs were significantly downregulated in neurosyphilis patients compared with healthy controls. Gene ontology (GO) analysis showed that the enriched mRNAs had significantly related functions, such as the defense response to fungi, the defense response to bacteria, killing cells of other organisms, and destroying cells of other organisms (Liu et al., 2017). LncRNAs are tissuespecific and often target multiple mRNAs; in addition, they can be used as potential biomarkers for disease diagnosis and prognosis evaluation (Schmitt and Chang, 2016). LncRNAENST00000421645 was significantly differentially expressed with a very low false discovery rate (FDR) in peripheral blood $\mathrm{CD} 4^{+} \mathrm{T}$ cells of neurosyphilis patients and healthy subjects. Whether the TP-induced expression of IncRNA-ENST00000421645 in $\mathrm{CD}^{+} \mathrm{T}$ lymphocytes is specific remains to be studied, and the potential mechanism underlying the effect of $\operatorname{lncRNA-}$ ENST00000421645 on the function of $\mathrm{CD} 4^{+} \mathrm{T}$ lymphocytes remains to be determined.

\section{MATERIALS AND METHODS}

\section{Cell Culture and Transfection Experiment}

Jurkat-E6-1 human leukemia T lymphocytes (purchased from Bnbio, Inc., Beijing, China) were cultured in RPMI 1640 (Invitrogen, Carlsbad, California, United States) medium supplemented with $10 \%(\mathrm{v} / \mathrm{v})$ heat-inactivated fetal bovine serum (Biological Industries Ltd., Kibbutz Beit HaEmek, Israel) at $37^{\circ} \mathrm{C}$ in a humidified atmosphere containing $5 \%$
$\mathrm{CO}_{2}$ LncRNA-ENST00000421645 was cloned into the GV502 plasmid (GeneChem Co., Ltd., Shanghai, China). The lentiviral vector and packaging vector were transfected into the packaging cell line 293T (ATCC) with Turbofect transfection reagent (Invitrogen) in accordance with the instruction manual. The lentivirus-containing medium was thus obtained. Then, $\mathrm{T}$ lymphocytes were transduced with the lentiviral vectors, and the stable cells were screened with puromycin $(5 \mu \mathrm{g} / \mathrm{mL})$. The lentiviral $\ln c R N A-E N S T 00000421645$ overexpression vector was transduced into $\mathrm{T}$ lymphocytes, and the resulting cells were called OE cells. The empty lentiviral vector was transduced into $\mathrm{T}$ lymphocytes, and the resulting cells were called NC cells. Kank1 small interfering RNA (siRNA) was transfected into OE cells, and the resulting cells were called OEsiRNA Kank1 cells. OE cells transfected with non-targeting control siRNA were called OEsiRNA NC cells.

\section{CCK-8 Assay}

The proliferation of T lymphocyte Jurkat-E6-1 cells, NC cells and $\mathrm{OE}$ cells was assessed at 24, 48, and $72 \mathrm{~h}$ after transfection. CCK-8 solution (10 $\mu \mathrm{L}$; Beyotime Biotechnology Co., Ltd.) was added and incubated for $3 \mathrm{~h}$, and the absorbance was measured at $450 \mathrm{~nm}$ as described previously (Wang et al., 2020).

\section{TUNEL Apoptosis Assay}

Cell samples (slides) were naturally dried and immersed in 4\% paraformaldehyde fixative solution for $30 \mathrm{~min}$ to improve the permeability of the cells. After soaking in PBS, 1\% Triton X-100 was added to the samples and incubated at room temperature for $15 \mathrm{~min}$. After washing, nuclease inactivation enzyme was added, and after another wash, protease $\mathrm{K}$ was added for cleanup. Then, $100 \mu \mathrm{L}$ of Streptavidin-TRITC-labeled working solution was added to each sample and soaked at $37^{\circ} \mathrm{C}$ in the dark for 1 h. After washing, DAPI was added for re-staining, and samples were observed under a fluorescence microscope after washing.

\section{Real-Time qPCR Assay}

The $\mathrm{T}$ lymphocytes were transduced with lentiviral IncRNAENST00000421645 overexpression vector and empty lentiviral vector, respectively. The experiment was repeated three times to obtain three groups of OE cells and NC cells that had been transformed for $24 \mathrm{~h}$. Kank1 small interfering RNA (siRNA) was transfected into OE cells and NC cells. After transfection for $24 \mathrm{~h}$, the OE cells, NC cells, OEsiRNA Kank1 and OEsiRNA NC cells were collected for RT-qPCR experiments. Total RNA was isolated from the cells using Trizol reagent (Life Technologies Corporation, Carlsbad, CA, United States). Total RNA yield and purity were analyzed spectrophotometrically (Denovix, United States) as previously reported (Chong, 2001). Then, First-strand cDNA was synthesized using a cDNA synthesis kit (Takara Biotechnology, Dalian, China) and SYBR Premix Ex Taq $^{\text {TM }}$ (Takara Biotechnology, Dalian, China). Two-step realtime fluorescence quantitative PCR for Kank1, 14-3-3 and IFN- $\gamma$ was used to detected the mRNA level of Kank1, 14-3-3 and IFN- $\gamma$. One microliters of each cDNA sample was amplified in a $20 \mu \mathrm{L}$ reaction mixture containing $10 \mu \mathrm{L}$ of SYBR premix Ex Taq II (2x) (Takara Biotechnology, Dalian, China), the forward primer and 
reverse primer at $0.25 \mu \mathrm{M}$ each, and $8 \mu \mathrm{L}$ Nuclease-Free Water in a 96-well reaction plate with a LightCycler ${ }^{\circledR} 480$ PCR-Time PCR System (Roche Diagnostics Ltd., Swit). The precise conditions for PCRs were as follows: in the pre-denaturation stage, the reaction cycle was repeated for $30 \mathrm{~s}$ at $95^{\circ} \mathrm{C}$; at the denaturation stage, the reaction time was $5 \mathrm{~s}$ at $95^{\circ} \mathrm{C}$, in the annealing extension phase, the reaction time was $35 \mathrm{~s}$ at $60^{\circ} \mathrm{C}$; and the denaturation and annealing extension stage was cycled for 40 times (distilled water and negative extraction control) were included in each assay. Three biological and technical replicates were performed. The specific primers used in real-time RT-PCR analyses were listed in Table 1.

Total RNA was extracted from NC cells, OE cells, OEsiRNA NC cells and OEsiRNA Kank1 cells and was subjected to reverse transcription. The cDNA product of reverse transcription was used as the template in subsequent experiments. $1 \mu \mathrm{L}$ of cDNA extracted from peripheral blood T cells among 3 clinical samples was used in this study and 4 different $\mathrm{T}$ cells from culture were dissolved in $9 \mu \mathrm{L}$ water, respectively. After the mixing process, $1 \mu \mathrm{L}$ of mixture was added into $9 \mu \mathrm{L}$ RNA-free water, followed by the same multiple dilution twice. Standard curves of target and reference genes were established from samples which were diluted to $1 \times 10^{5}, 1 \times 10^{4}, 1 \times 10^{3}, 1 \times 10^{2}$, and $1 \times 10^{1}$. The $E$-values and corresponding $R^{2}$ values were shown in Table 2. The melting curve of PCR showed that PCR amplification had specificity, with only one specific peak, no primer-dimers and no non-specific amplification products. The results showed that the slope differences of standard curves between $\ln c$ RNA-ENST00000421645 mRNA and $\beta$-actin mRNA, IFN- $\gamma$ mRNA and GAPDH mRNA, Kank 1 mRNA and GAPDH mRNA, 14-3-3 mRNA and GAPDH mRNA were less than 0.1, respectively; therefore, we employed 2- $\Delta \Delta \mathrm{Ct}$ method (Livak and Schmittgen, 2001) to calculate the relative expression level of the target gene. The $\mathrm{C}_{t}$ value was adjusted automatically and the threshold cycle value difference $\left(\Delta \mathrm{C}_{\mathrm{t}}\right)$ between FAM $\mathrm{C}_{\mathrm{t}}$ of the target gene (IncRNA- ENST00000421645, Kank1, 14-33 , and $I F N-\gamma$ ) and FAM $\mathrm{C}_{\mathrm{t}}$ of GAPDH (internal control) was used to normalize the amount of Kank1, 14-3-3 and IFN- $\gamma$. As long as the target gene and the internal control have similar amplification efficiencies, $C_{t}$ values are normalized by using the difference $\left(\Delta C_{t}\right)$ between the internal control and target gene. This value is calculated for each sample to be quantified. Finally, the amount of Kank1, 14-3-3 and IFN- $\gamma$, normalized to an endogenous reference and relative to a calibrator, is given

TABLE 1 | Primer sequences were shown below.

\begin{tabular}{lll}
\hline & Forward $\mathbf{5}^{\prime} \mathbf{-} \mathbf{3}^{\prime}$ & Reverse $^{\mathbf{\prime}} \mathbf{- \mathbf { 3 } ^ { \prime }}$ \\
\hline IFN- $\boldsymbol{\gamma}$ & AGAGTGTGGAGA & TGCGTTGGACAT \\
Kank1 & CCATCAAGGA & TCAAGTCAGT \\
& AACAGGCAGCAA & CCACAACCGAT \\
$14-3-3$ & CACAGAGGAG & AGACCGCACTT \\
& TGCTGAAGTTGC & GCGGATTGGG \\
GAPDH & GTGTGGTGT & TGTGTGGGTT \\
& GAGTCAACGGA & GACAAGCTTC \\
& TTGGTCGT & CCGTTCTCAG
\end{tabular}

TABLE 2 | The standard curve indexes of IFN- $\gamma$, Kank1,14-3-3 and GAPDH genes in four different cells were shown below.

\begin{tabular}{|c|c|c|c|c|}
\hline Cell name & Gene name & $\mathbf{E}$ & $\mathbf{R}^{2}$ & $\operatorname{Tm}\left({ }^{\circ} \mathrm{C}\right)$ \\
\hline $\mathrm{NC}$ & $I F N-\gamma$ & 2.047 & 0.9887 & 82.98 \\
\hline $\mathrm{NC}$ & Kank1 & 2.062 & 0.9920 & 81.82 \\
\hline $\mathrm{NC}$ & $14-3-3$ & 2.058 & 0.9985 & 87.13 \\
\hline $\mathrm{NC}$ & GAPDH & 2.048 & 0.9986 & 84.37 \\
\hline OE & $I F N-\gamma$ & 1.978 & 0.9986 & 82.78 \\
\hline OE & Kank1 & 2.003 & 0.9980 & 81.80 \\
\hline OE & $14-3-3$ & 2.001 & 0.9985 & 87.33 \\
\hline OE & GAPDH & 2.000 & 0.9973 & 84.71 \\
\hline OEsiRNA NC & $I F N-\gamma$ & 2.078 & 0.9901 & 82.81 \\
\hline OEsiRNA NC & Kank1 & 2.098 & 0.9878 & 81.71 \\
\hline OEsiRNA NC & $14-3-3$ & 2.055 & 0.9910 & 87.07 \\
\hline OEsiRNA NC & GAPDH & 2.080 & 0.9966 & 84.32 \\
\hline OEsiRNA Kank1 & $I F N-\gamma$ & 2.081 & 0.9921 & 82.65 \\
\hline OEsiRNA Kank1 & Kank1 & 2.084 & 0.9912 & 81.90 \\
\hline OEsiRNA Kank1 & $14-3-3$ & 2.061 & 0.9843 & 87.58 \\
\hline OEsiRNA Kank1 & GAPDH & 2.074 & 0.9836 & 84.67 \\
\hline
\end{tabular}

NC: T lymphocytes transfected with empty lentiviral vector, OE: T lymphocytes transfected with IncRNA-ENSTO0000421645 overexpression lentiviral vector, OEsiRNA NC: OE cells transfected with non-targeting control SiRNA, OEsiRNA Kank1:OE cells transfected with Kank1 small interfering RNA (siRNA), E: Efficiency, $R^{2}$ : coefficient of determination, Tm: Melting Temperature.

by:

$$
\begin{aligned}
& \text { Relative Quantification }=2^{-\Delta \Delta \mathrm{Ct}} \\
& \text { Where } \Delta \Delta \mathrm{C}_{\mathrm{t}}=\Delta \mathrm{C}_{\mathrm{t}} \text { (Experimental sample) } \\
& -\Delta \mathrm{C}_{\mathrm{t}} \text { (Control sample). } \\
& \Delta \mathrm{Ct}=\mathrm{Ct} \text { (Target gene) }-\mathrm{Ct} \text { (Reference gene). }
\end{aligned}
$$

\section{ELISA}

After transfection for $24 \mathrm{~h}$, the IFN- $\gamma$ concentration in the OE cells, NC cells, OEsiRNA Kank1 and OEsiRNA NC cells culture supernatant was determined with an Human IFNgamma ELISABASIC kit (HRP) (Neobioscience Technology Co., Ltd., China) according to the manufacturer's instructions. IFN- $\gamma$ ELISA kits were solid-phase sandwich enzyme-linked immunosorbent assays. The kit contains a matched pair of monoclonal capture and detection antibodies, Streptavidin-HRP, ELISA standard and standard reconstitution buffer.

\section{Western Blot Analysis}

The cells were washed with PBS for three times and then added with cell lysate RIPA (1-5 × $10^{6}$ cells added with $250 \mu \mathrm{L}$ lysate). The whole process was carried out on ice. The cells were then lysed by ultrasound, and the power was adjusted to $28 \%$ for about $10 \mathrm{~s}$ until the cell suspension became clear. After ultrasonic lysis, the cells were placed on ice for $30 \mathrm{~min}$, and then cell lysis solution was collected and centrifuged at 13,200 rpm at $4^{\circ} \mathrm{C}$ for $30 \mathrm{~min}$. The supernatant was carefully absorbed (be careful not to remove precipitation) into a clean $1.5 \mathrm{~mL}$ EP tube. $5 \times$ loading buffer, 0.25 times of supernatant volume, was added and fully mixed, heated at $100^{\circ} \mathrm{C}$ for $10 \mathrm{~min}$ and stored 
at $-20^{\circ} \mathrm{C}$ for later use. The membrane transfer process begins immediately after electrophoresis. Then the membrane was incubated first with anti-14-3-3, anti-kank1, anti-p-ikba, antit-ikba (all 1:1,000; Abcam, Cambridge, Ma, United States) and anti-GAPDH (1:1,000, Cell Signaling Technology, Danvers, MA, United States) antibodies and then with horseradish peroxidaseconjugated secondary antibodies. Western Chemiluminescent HRP 149 Substrate (ECL, Millipore, United States) was used to visualize the immunoreactivity bands. The images were quantified using Image J software.

\section{Chromatin Immunoprecipitation-PCR Assay}

ChIP was used to investigate the binding of histone H3K27 to the target gene Kank1 in NC cells and OE cells. After $48 \mathrm{~h}$ of culture, the chromatin in the cells was first cross-linked using $1 \%$ formaldehyde, and the cells were subjected to fixation followed by lysis and enzymatic digestion. Immunoprecipitation was then conducted. The IgG ChIP antibody ( $2 \mu$ g, Cell Signaling Technology, Danvers, MA, United States) and the anti-H3K27 ChIP antibody (2 $\mu \mathrm{g}$, Cambridge, Ma, United States) (Liu et al., 2021) were added. The immunoprecipitation reaction was performed for $2 \mathrm{~h}$; samples were incubated on a shaking platform at $4^{\circ} \mathrm{C}$ overnight. After elution of the immunoprecipitates, the DNA was purified. Enrichment of histone H3K27 and the target gene Kank1 was detected by RT-qPCR. All samples were tested in triplicate, and three multiple holes were made in each experiment.

\section{RNA Pull-Down Assay}

Streptavidin-conjugated magnetic beads were used to pull down IncRNA-ENST00000421645 according to the manual for the Pierce $^{\mathrm{TM}}$ Magnetic RNA-Protein pull-down kit (Thermo Fisher Scientific, United States). Biotinylated RNA and T lymphocyte lysates were mixed and incubated. Streptavidin-agarose beads

A
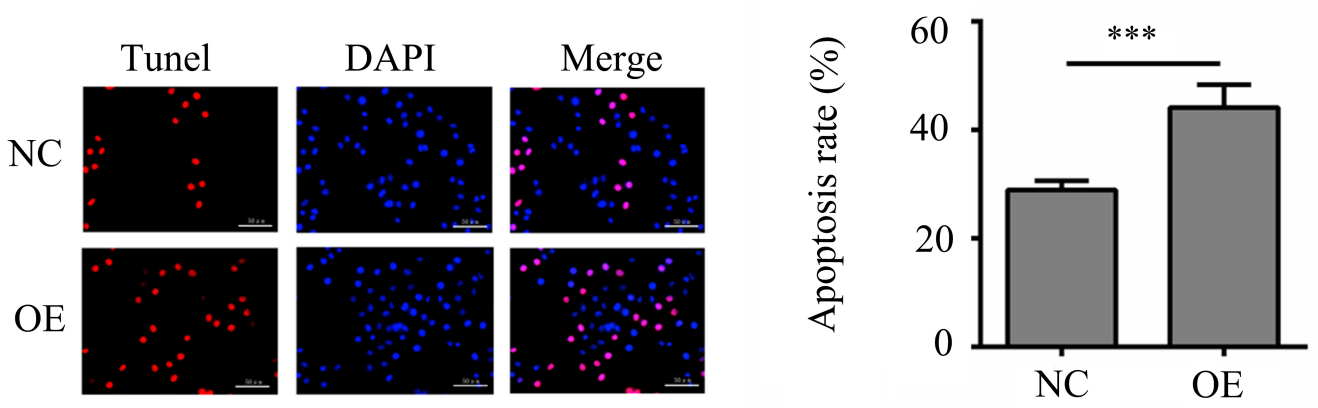

B
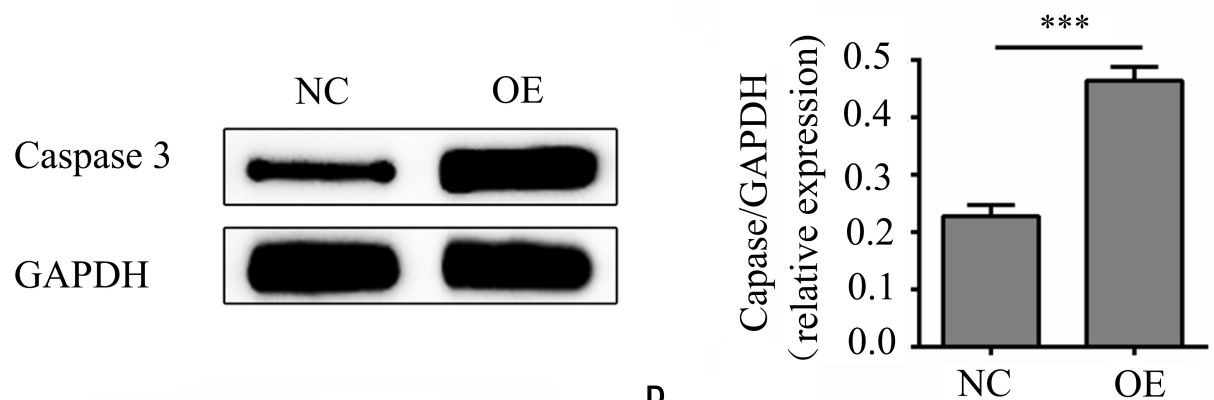

C

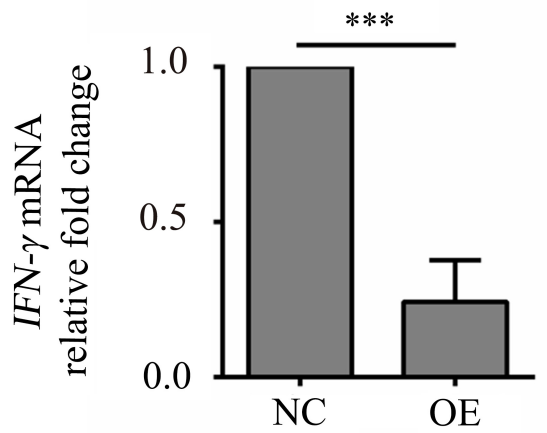

D

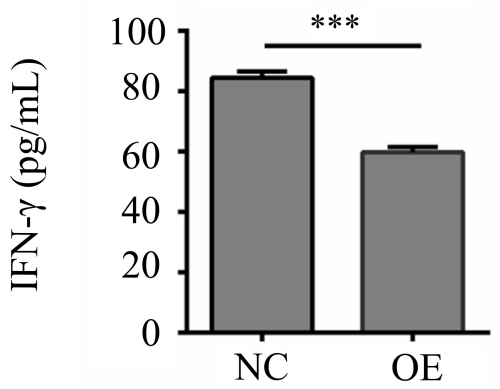

FIGURE 1 | Effects of InCRNA-ENST00000421645 on apoptosis and secretion of IFN- $\gamma$ in T lymphocytes. (A) Apoptosis was detected in T lymphocytes transfected with empty lentiviral vector (NC cells) and T lymphocytes transfected with IncRNA-ENST00000421645 overexpression lentiviral vector (OE cells) with a TUNEL apoptosis detection kit. (B) The protein level of caspase3 in NC cells and OE cells was determined by Western blot analysis. (C) The relative fold change in IFN- $\gamma$ mRNA expression in NC cells and OE cells was determined by RT-qPCR. (D) The IFN- $\gamma$ protein concentration in NC cells and OE cells was measured by ELISA $\left.{ }^{* * *} P<0.001\right)$. Student's $t$-test was used for comparisons between two groups. Two-tailed $P$-values less than 0.05 were considered statistically significant. 
were added to each binding reaction, and the mixtures were incubated at $4^{\circ} \mathrm{C}$ for $1 \mathrm{~h}$ prior to two elution steps with detergent solution. The eluted proteins were detected by mass spectrometry (MS).

\section{Statistical Analysis}

Continuous variables are presented in the form of mean \pm standard deviation. Non-normal distribution parameters are described by median \pm interquartile range. The expression level of 14-3-3 mRNA level was analyzed by using rank sum test. The multiple comparison of 14-3-3 expression level was conducted using Kruskal-Wallis test. The apoptosis rates of OEsiRNA NC cells and OEsiRNA, and the mRNA level and protein level of these two cell lines were analyzed by using Student's $t$-test. One-way ANOVA was employed to compare the mRNA levels that measured from more than two groups, and SNK test was used for conducting multiple comparisons. All statistical analyses were performed in SPSS version 20 and a $P$-value less than 0.05 was considered significant.

\section{Ethics Approval Statement}

This study was approved by the Ethics Committee of Zhongshan Hospital (NO. 2021-147) and was in accordance with the Helsinki Declaration. Participants signed written informed consent prior to participating in the study.

\section{RESULTS}

\section{LncRNA-ENST00000421645 Mediates Apoptosis in T Lymphocytes and Inhibited the Secretion of IFN- $\gamma$}

In order to study on the mechanistic of $\operatorname{lncRNA-}$ ENST00000421645 based on our previous study (Liu et al., 2017), the vector GV502 was used to construct the lentiviral IncRNAENST00000421645 overexpression vector. T lymphocytes were transduced with lentiviral vectors. After transduction for $24 \mathrm{~h}$, the apoptosis rates of NC cells OE cells were $28.91 \pm 3.58 \%$ and $44.12 \pm 5.24 \%$, respectively. The apoptosis rate of OE cells was significantly increased compared with that of NC cells $(P<0.001$, Figure 1A). Caspase3 is closely related to cell apoptosis. To further confirm the effect of IncRNA-ENST00000421645 on T lymphocyte apoptosis, the expression of caspase 3 in NC cells and OE cells was analyzed by Western blotting after transduction for $24 \mathrm{~h}$. The relative caspase 3 protein level in NC cells was found to be $0.228 \pm 0.019$. The relative caspase 3 protein expression level in $\mathrm{OE}$ cells was $0.464 \pm 0.024$, indicating significant upregulation $(P<0.001$, Figure 1B). These results suggested

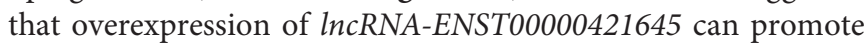
apoptosis in $\mathrm{T}$ lymphocytes.

The samples of IFN- $\gamma$ had a similar PCR efficiency to samples containing GAPDH. The relative fold change in IFN- $\gamma$ mRNA expression in $\mathrm{OE}$ cells compared to NC cells was 0.23, a significant decrease $(P<0.001$, Figure 1C). In addition, the ELISA results were consistent with the RT-qPCR results. By ELISA, the IFN- $\gamma$ protein concentration was determined to be
$84.47 \pm 7.63 \mathrm{pg} / \mathrm{mL}$ in NC cells and $59.77 \pm 7.65 \mathrm{pg} / \mathrm{mL}$ in $\mathrm{OE}$ cells. Thus, compared with that in NC cells, the content of IFN$\gamma$ in OE cells was significantly reduced $(P<0.001$, Figure 1D). These results showed that $\ln C R N A-E N S T 00000421645$ inhibits the secretion of IFN- $\gamma$.

\section{LncRNA-ENST00000421645 Affects the Expression of the Adjacent Gene Kank1}

According to lncRNA expression profile analysis, the gene

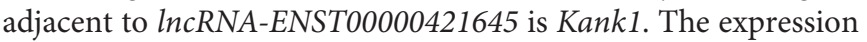
of Kank1 in OE cells was analyzed by Western blotting, and the relative Kank1 protein expression level in NC cells was found to be $0.277 \pm 0.021$. The relative Kank1 protein expression level in OE cells was $0.773 \pm 0.021$, indicating significant upregulation $(P<0.001$, Figure 2).

\section{LncRNA-ENST00000421645-Regulated Acetylation of Histone H3K27 Adjacent to the Kank1 Promoter Promotes the Expression of Kank1}

Bioinformatics showed that the adjacent gene of $\operatorname{lncRNA}$ ENST00000421645 is Kank1 according to our previous published paper (Liu et al., 2017). To investigate the mechanism by which IncRNA-ENST00000421645 upregulates the expression of the adjacent gene Kank1, a IncRNA-ENST00000421645 pull-down assay was performed with streptavidin-conjugated magnetic beads. The precipitated product was analyzed by mass spectrometry to identify the $\operatorname{lncRNA-ENST00000421645}$ interacting proteins. A total of 793 proteins were identified in the sense group, and 638 proteins were identified in the anti-sense group. Mass spectrometry analysis of the precipitated products revealed 155 differential proteins. The top ten differential proteins were listed in Table 3. The changes in chromatin structure caused by the modification of histones play an important role in the regulation of gene expression and transcription. Among them, histone acetylation is particularly important. The acetylation of the $\mathrm{N}$-terminal lysine residues of histones in eukaryotic cells is related to the transcriptional activation of genes. We analyzed that among the top 10 proteins

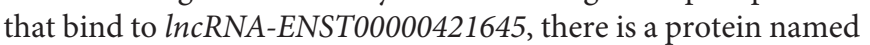
NAT10 related to acetylation. The acetylase NAT10 ranked ninth,

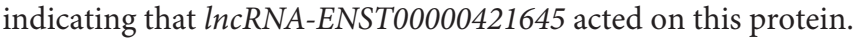

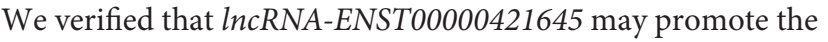
acetylation of histone $\mathrm{H} 3 \mathrm{~K} 27$ adjacent to the Kank1 promoter through the acetylase NAT10, thus promoting the expression of Kank1. ChIP-PCR was performed on OE cells and NC cells. An anti-H3K27 antibody was used to precipitate the cross-linked DNA-protein complexes. Primers targeting the Kank1 promoter sequence were designed, and the DNA sequence enriched by the anti-H3K27 antibody was detected by real-time PCR. The samples of Kank1 had a similar PCR efficiency to samples containing GAPDH. The enrichment of the Kank1 gene promoter in the non-H3K27-acetylated group of OE cells was significantly increased 3.96-fold compared with that in NC cells $(P<0.001$, Figure 3). These results suggest that $\operatorname{lncRNA-ENST00000421645}$ promotes the acetylation of histone H3K27 adjacent to the Kank1 

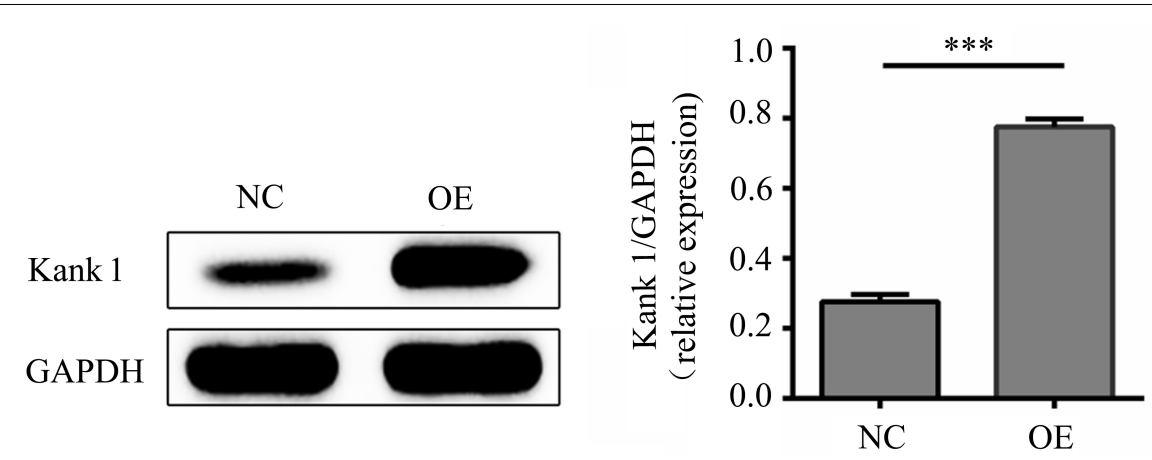

FIGURE 2 | The protein level of Kank1 in NC cells and OE cells was determined by Western blot analysis. The relative protein expression level of Kank1 in OE cells was significantly increased compared to that in NC cells $\left(77.33 \pm 2.08 \%\right.$ vs. $27.67 \pm 2.08 \%$, $\left.{ }^{\star \star \star} P<0.001\right)$. Student's $t$-test was used for comparisons between two groups. Two-tailed $P$-values less than 0.05 were considered statistically significant.

promoter, thereby promoting Kank1 expression. All samples were tested in triplicate.

\section{LncRNA-ENST00000421645 Promotes Kank1 and 14-3-3 Protein Expression and Inhibits NF-kB Pathway Activation}

Kank1 siRNA was used to knock down Kank1 gene expression in OE cells, and RT-qPCR was then used to detect the knockdown efficiency and select the siRNA with the highest efficiencyKank1-776-for subsequent experiments ( $P<0.001$, Figure 4A). The relative fold change in the Kank1 mRNA level in OE cells

TABLE 3 | Top fifteen differential proteins were listed below.

\begin{tabular}{|c|c|c|c|}
\hline $\begin{array}{l}\text { Sequential } \\
\text { number }\end{array}$ & Peptides & $\begin{array}{l}\text { Unique } \\
\text { peptides }\end{array}$ & Group description \\
\hline 1 & 19 & 7 & $\begin{array}{l}\text { DNA topoisomerase 2-beta OS }=\text { Homo } \\
\text { sapiens } \mathrm{GN}=\mathrm{TOP} 2 \mathrm{~B} \mathrm{PE}=1 \mathrm{SV}=3\end{array}$ \\
\hline 2 & 10 & 6 & $\begin{array}{l}\text { CLIP-associating protein } 2 \text { OS }=\text { Homo } \\
\text { sapiens } \mathrm{GN}=\mathrm{CLASP} 2 \mathrm{PE}=1 \mathrm{SV}=1\end{array}$ \\
\hline 3 & 5 & 1 & $\begin{array}{l}\text { Y-box-binding protein } 3 \mathrm{OS}=\text { Homo } \\
\text { sapiens } \mathrm{GN}=\mathrm{YBX} 3 \mathrm{PE}=1 \mathrm{SV}=4\end{array}$ \\
\hline 4 & 7 & 7 & $\begin{array}{l}\text { AT-rich interactive domain-containing } \\
\text { protein } 1 \mathrm{~A} \text { OS }=\text { Homo sapiens } \\
\mathrm{GN}=\mathrm{ARID1A} \text { PE }=1 \mathrm{SV}=2\end{array}$ \\
\hline 5 & 7 & 7 & $\begin{array}{l}\text { AT-rich interactive domain-containing } \\
\text { protein } 1 \mathrm{~A} \text { (Fragment) } \mathrm{OS}=\text { Homo sapiens } \\
\mathrm{GN}=\mathrm{ARID1A} P E=1 \mathrm{SV}=1\end{array}$ \\
\hline 6 & 7 & 7 & $\begin{array}{l}\text { AT-rich interactive domain-containing } \\
\text { protein } 1 \mathrm{~A} \mathrm{OS}=\text { Homo sapiens } \\
\mathrm{GN}=\text { ARID1A PE }=1 \mathrm{SV}=3\end{array}$ \\
\hline 7 & 9 & 6 & $\begin{array}{l}\text { ATP-dependent RNA helicase DDX3Y } \\
\text { OS }=\text { Homo sapiens } \mathrm{GN}=\mathrm{DDX} 3 \mathrm{Y} \text { PE }=1 \\
\mathrm{SV}=2\end{array}$ \\
\hline 8 & 6 & 6 & $\begin{array}{l}\text { Ubiquitin-associated protein } 2 \text {-like } \\
\text { OS }=\text { Homo sapiens } \mathrm{GN}=\text { UBAP2L PE }=1 \\
\text { SV }=2\end{array}$ \\
\hline 9 & 9 & 9 & $\begin{array}{l}\text { RNA cytidine acetyltransferase OS }=\text { Homo } \\
\text { sapiens } \mathrm{GN}=\text { NAT10 PE }=1 \mathrm{SV}=2\end{array}$ \\
\hline 10 & 5 & 2 & $\begin{array}{l}\text { Polyadenylate-binding protein } \mathrm{OS}=\text { Homo } \\
\text { sapiens } \mathrm{GN}=\mathrm{PABPC} 4 \mathrm{PE}=1 \mathrm{SV}=1\end{array}$ \\
\hline
\end{tabular}

compared with $\mathrm{NC}$ cells was $6.52 \pm 1.75$, a significant increase compared with the level in NC cells $(P<0.001$, Figure 4B). The relative fold change in the Kank1 mRNA level in OEsiRNA NC cells compared with OE cells was $6.18 \pm 1.27$, a difference that was not significant. The relative fold change in the Kank1 mRNA level in OEsiRNA Kank1 cells was $1.89 \pm 0.38$, a significant reduction compared with that in OEsiRNA NC cells $(P<0.01$, Figure 4B). Kank 1 has also been shown to promote 14-3-3 protein expression to inhibit NF-kB activation (Kakinuma et al., 2008). The samples of 14-3-3 had a similar PCR efficiency to samples containing GAPDH. The relative fold change in the 143-3 mRNA level in OE cells was $4.88 \pm 0.58$, a significant increase compared with that in NC cells $(P<0.001$, Figure 4C). The relative fold change in the 14-3-3 mRNA level in OEsiRNANC cells compared with OE cells was $5.43 \pm 0.59$, a difference that was not significant. The relative fold change in the 14-3-3 mRNA level in OEsiRNA Kank1 cells was $2.93 \pm 0.40$, a significant reduction compared to that in OEsiRNA NC cells

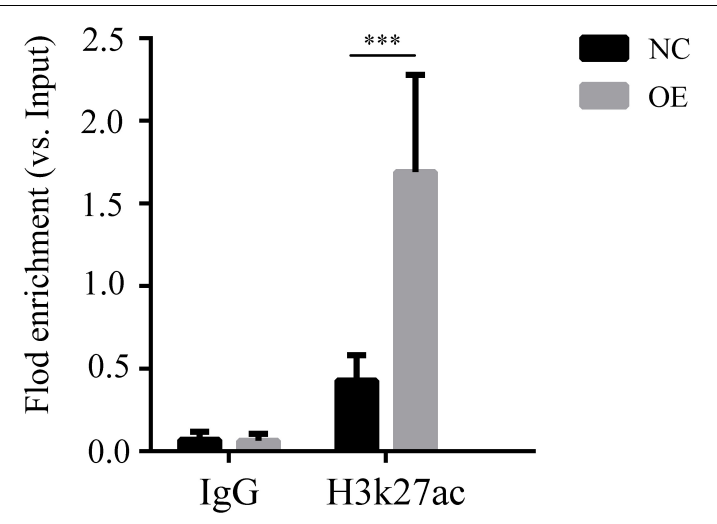

FIGURE 3 | Acetylation of histone H3K27 adjacent to the Kank1 promoter was detected by ChIP. All samples were tested in triplicate, and three multiple holes were made in each experiment. Enrichment of the target gene Kank1 was detected by RT-qPCR (***P $<0.001)$. Student's $t$-test was used for comparisons between two groups. Two-tailed $P$-values less than 0.05 were considered statistically significant. 
A

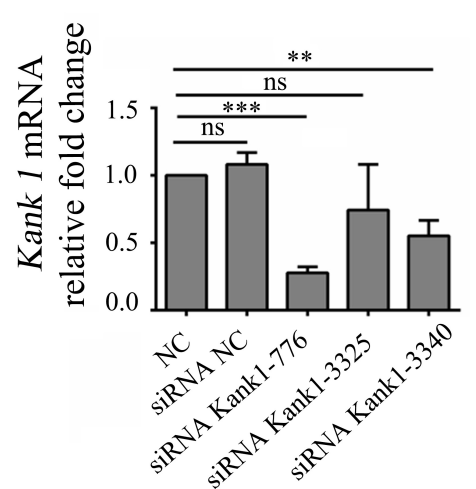

B
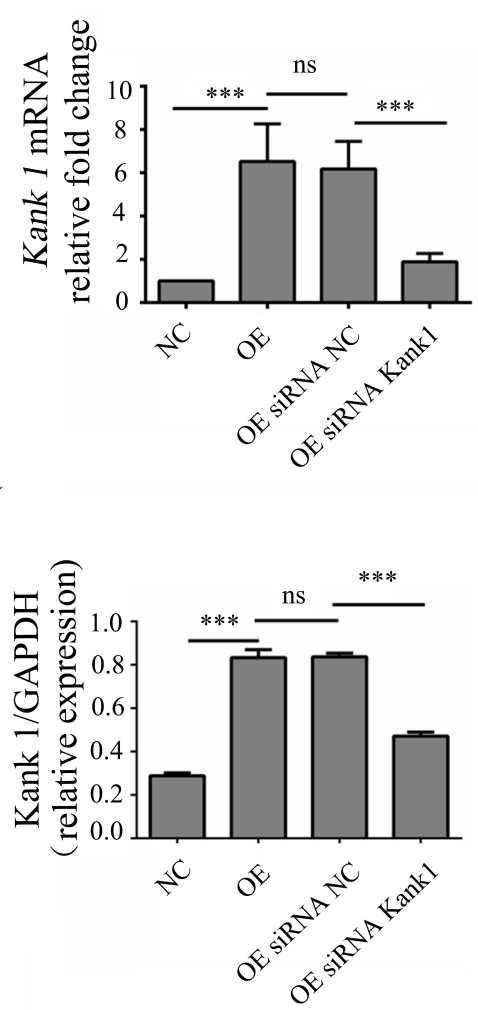

C

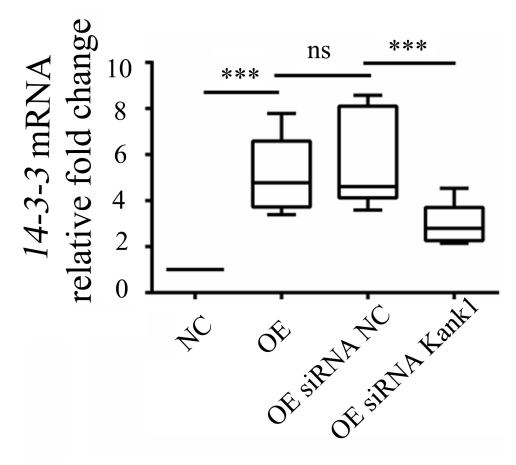

D
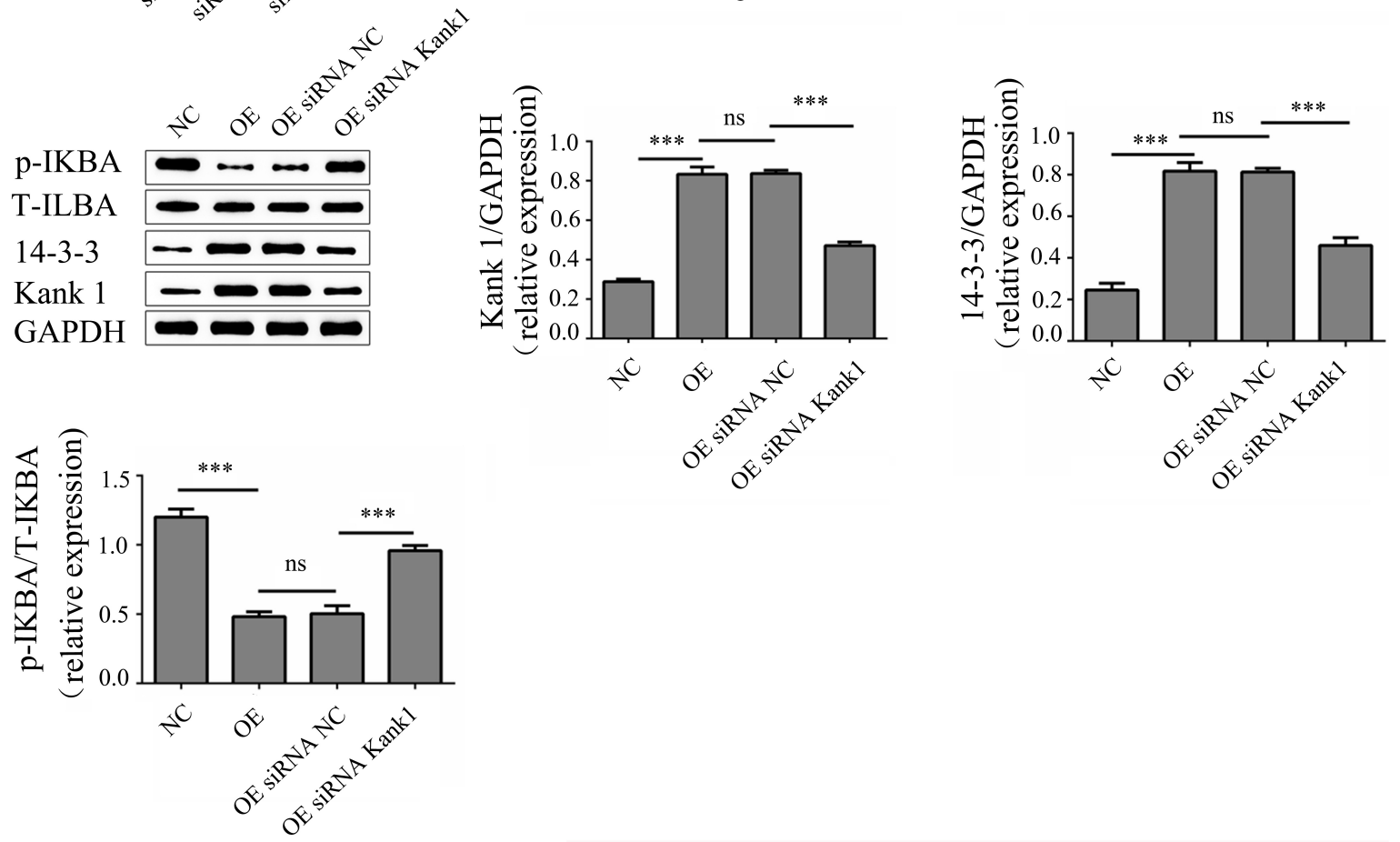

FIGURE 4 | LnCRNA-ENST00000421645 promoted the protein expression of Kank1 and 14-3-3 and inhibited NF-kB pathway activation. (A) The Kank1 gene knockdown efficiency of dKank1 siRNA in T lymphocytes was evaluated by RT-qPCR, and the siRNA with the highest efficiency - Kank1-776-was selected. (B) The relative mRNA level of Kank1 in NC cells, OE cells, OEsiRNA NC cells, and OEsiRNA Kank1 cells was determined by RT-qPCR. (C) The relative mRNA level of 14-3-3 in NC cells, OE cells, OEsiRNA NC cells, and OEsiRNA Kank1 cells was determined by RT-qPCR. (D) The protein levels of $p$-IKBA, T-IKBA, 14-3-3 and Kank1 in NC cells, OE cells, OEsiRNA NC cells and OEsiRNA Kank1 cells were determined by Western blot analysis $\left({ }^{* *} P<0.01,{ }^{* * *} P<0.001\right) .14-3-3$ mRNA level was analyzed by using rank sum test. The multiple comparison of 14-3-3 expression level was conducted using Kruskal-Wallis test. Kank1 mRNA and protein level of p-IKBA, T-IKBA, 14-3-3 and Kank1 were analyzed by using One-way ANOVA, and SNK test was used for conducting multiple comparison. $P$-values less than 0.05 were considered statistically significant.

$(P<0.01$, Figure 4C). In addition, the Western blot results were consistent with the RT-qPCR results. The relative Kank1 protein levels in NC cells, OE cells, OEsiRNA NC cells and OEsiRNA Kank1 cells were $0.288 \pm 0.013,0.833 \pm 0.037$, $0.837 \pm 0.017$, and $0.471 \pm 0.018$, respectively. The Kank1 protein level in OEsiRNA Kank1 cells was significantly lower than that in OEsiRNA NC cells $(P<0.001$, Figure 4D). The relative 14-3-3 protein levels in NC cells, OE cells, OEsiRNA NC cells and OEsiRNA Kank 1 cells were $0.246 \pm 0.033,0.817 \pm 0.043$, $0.813 \pm 0.018$, and $0.460 \pm 0.037$, respectively. The relative $14-3-3$ protein expression level was also reduced in OEsiRNA Kank1 cells compared with OEsiRNA NC cells $(P<0.001$, Figure 4D).

The phosphorylation level of IKBa can indirectly reflect the activation of the NF-kB signaling pathway. P-IKBa/T-IKBa refers to the ratio of phosphorylated IKBa protein to total IKBa protein content, which can reflect the activation degree of NF-kB pathway. Thus, the phosphorylation level of IKBa was analyzed by Western blotting. The relative $\mathrm{p}-\mathrm{IKBa} / \mathrm{IKBa}$ ratios in NC cells, OE cells, OEsiRNA NC cells and OEsiRNA Kank1 cells were $1.200 \pm 0.058,0.482 \pm 0.035,0.503 \pm 0.058$, and 
$0.958 \pm 0.038$, respectively. Compared with that in NC cells, the relative $\mathrm{p}-\mathrm{IKBa} / \mathrm{IKB}$ a ratio was significantly reduced in $\mathrm{OE}$ cells $(P<0.001$; Figure 4D). Compared with that in OEsiRNA NC cells, the relative $\mathrm{p}-\mathrm{IKBa} / \mathrm{IKBa}$ ratio was obviously increased in OEsiRNA Kank1 cells $(P<0.001$, Figure 4D).

This analysis showed that IncRNA-ENST00000421645 upregulated the expression of Kank1. Kank1 promoted 14-3-3 protein expression and inhibited NF-kB activation.

\section{LncRNA-ENST00000421645 Promotes Apoptosis and Inhibits IFN- $\gamma$ Secretion Through Kank1 in T Lymphocytes}

The effect of the IncRNA-ENST00000421645-Kank1 protein interaction on $\mathrm{T}$ lymphocyte function was further investigated. The apoptosis rates of OEsiRNA NC cells and OEsiRNA Kank1 cells were $42.35 \pm 4.16 \%$ and $21.50 \pm 3.81 \%$, respectively. Compared with that of OEsiRNA NC cells, the apoptosis rate of OEsiRNA Kank1 cells was significantly reduced $(P<0.001$, Figure 5A). To further confirm the effect of Kank1 on $T$ lymphocyte apoptosis, after transfection for $24 \mathrm{~h}$, the expression of caspase 3 in OE siRNA NC cells and OE siRNA Kank1 cells was analyzed by Western blotting. The relative caspase-3 protein expression level was significantly decreased in OE siRNA Kank1 cells compared with OE siRNA NC cells $(0.347 \pm 0.034$ vs. $0.829 \pm 0.035, P<0.001$; Figure 5B). The relative fold change in the IFN- $\gamma$ mRNA level in OE siRNA Kank1 cells compared with OEsiRNA NC cells was $2.88 \pm 0.65$, a significant increase $(P<0.001$, Figure 5C). In addition, the ELISA results were consistent with the RT-qPCR results. The IFN- $\gamma$ protein levels in OEsiRNA Kank1 and OEsiRNA NC cells were $83.20 \pm 4.86$ $\mathrm{pg} / \mathrm{mL}$ and $64.42 \pm 5.30 \mathrm{pg} / \mathrm{mL}$, respectively. Compared with that in OE siRNA NC cells, the IFN- $\gamma$ level in OE siRNA Kank1 cells was obviously increased $(P<0.001$, Figure 5D). These results

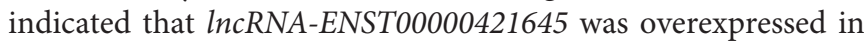
$\mathrm{T}$ lymphocytes of neurosyphilis patients, resulting in promotion of apoptosis and inhibition of IFN- $\gamma$ secretion through the Kank1 protein. The mechanistic diagram of T lymphocyte regulation by lncRNA-ENST00000421645 was shown in Figure 6.

\section{DISCUSSION}

Previous studies have shown that many lncRNAs are involved in regulating the immune response in response to pathogen invasion (Jiang et al., 2018). Li et al. (2016) found that the lncRNA NRON in CD $4^{+}$T cells can specifically downregulate Tat protein expression and is beneficial to latent HIV-1 virus in vivo. Yao et al. found that Helicobacter pylori infection can activate the SGK1/JunB signaling pathway to enhance the expression of the lncRNA LNC-SGK1 and induce an increase in CD4 ${ }^{+} \mathrm{T}$ cell differentiation into Th2 and Th17 cells and a decrease in differentiation into Th1 cells (Yao et al., 2016). Serum Lnc-SGK1 expression is associated with poor prognosis in patients with gastric cancer. Our previous study suggests increased expression of IncRNA-ENST00000421645 was found in CD4 ${ }^{+} \mathrm{T}$ cells from neurosyphilis patients compared to healthy controls (Liu et al., 2017), but its function is unclear.
Recently, researchers have begun to study the function of lncRNAs and have found that IncRNAs can affect cell proliferation, migration, differentiation, apoptosis, and other physiological processes (Jou et al., 2019; Wang et al., 2019; Xie et al., 2019). In this study, we demonstrated that $\operatorname{lncRNA-}$ ENST00000421645 can promote apoptosis in $\mathrm{T}$ lymphocytes and inhibit IFN- $\gamma$ secretion. LncRNA-ENST00000421645 was overexpressed in a T lymphocyte line (Jurkat-E6-1), and IncRNAENST00000421645 was found to promote the expression of the apoptosis-related protein caspase 3 in $\mathrm{T}$ lymphocytes and promote $\mathrm{T}$ lymphocyte apoptosis. Caspase 3 is a major effector caspase and is a common downstream effector molecule of multiple apoptotic pathways that plays a central role in the process of apoptosis; thus, it is called a "death executing protease (Li et al., 1997; Porter and Jänicke, 1999; Winstel et al., 2019; Soleimani and Sajedi, 2020). Our findings suggested that $\operatorname{lncRNA-}$ ENST00000421645 induced apoptosis in T lymphocytes through the caspase pathway.

To explore the mechanism by which $\operatorname{lncRNA-}$ ENST00000421645 promotes $\mathrm{T}$ lymphocyte apoptosis and inhibits IFN- $\gamma$ secretion, a series of additional experiments were carried out. Our previous experiments showed through nuclear separation technology that IncRNA-ENST00000421645 exists mainly in the cytoplasm (results not shown). Cytoplasmic lncRNAs play a role in post-transcriptional regulation mainly by regulating mRNA degradation and protein translation (Nance et al., 2020). Previous bioinformatic analysis showed that Kank1 was an adjacent gene of IncRNA-ENST00000421645. In addition, Kank1 is a documented tumor suppressor gene that inhibits the proliferation, migration, and invasion of tumor cells (gastric cancer, lung cancer, etc.) and promotes their apoptosis. This study demonstrated that IncRNA-ENST00000421645 can upregulate the expression of the neighboring gene Kank1. The interaction between IncRNA-ENST00000421645 and NAT10 was proven by RNA immunoprecipitation with mass spectrometry. NAT10 is a histone acetyltransferase and promotes histone acetylation and chromosome depolymerization, thus promoting transcription and translation. In this study, ChIP-PCR showed that IncRNA-ENST00000421645 promoted the acetylation of histone H3K27 adjacent to the Kank1 promoter and thus promoted Kank1 expression. Increased Histone acetylation can loosens the chromatin structure and facilitates transcription.

We further explored the mechanism of $\operatorname{lncRNA-}$ ENST00000421645 through upregulation of Kank1. In this study, Kank1 gene expression was knocked down in OE cells. When Kank1 expression was knocked down, caspase 3 expression was downregulated, indicating that $\operatorname{lncRNA-ENST00000421645}$ promoted apoptosis in $\mathrm{T}$ lymphocytes by upregulating Kank1 protein expression.

Kank1 has also been shown to promote 14-3-3 protein expression to inhibit NF-kB activation (Kakinuma et al., 2008). Although the 14-3-3 protein has no intrinsic protease activity, it has a wide range of biological functions. It participates in regulating cell signal transduction, cell metabolism, cell invasion, and many other cellular physiological activities. $\mathrm{NF}-\mathrm{kB}$ is an important transcriptional regulator in the nucleus that can promote cell proliferation and inhibit apoptosis. 
A

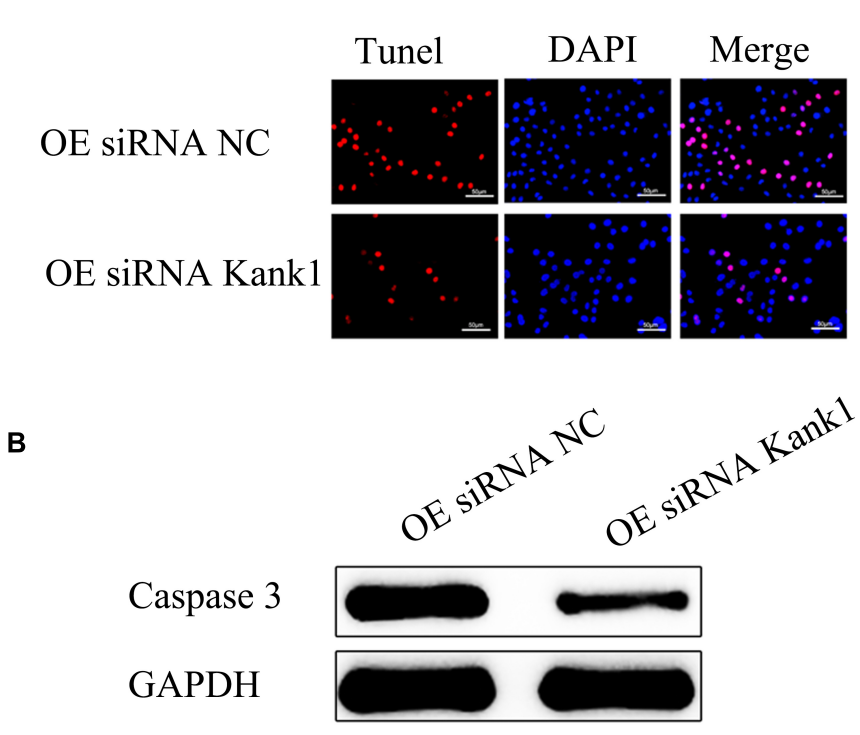

C

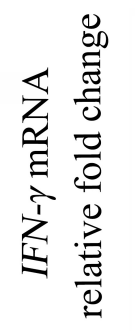

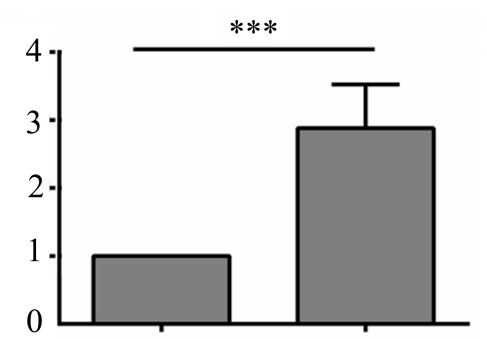

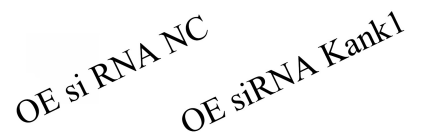

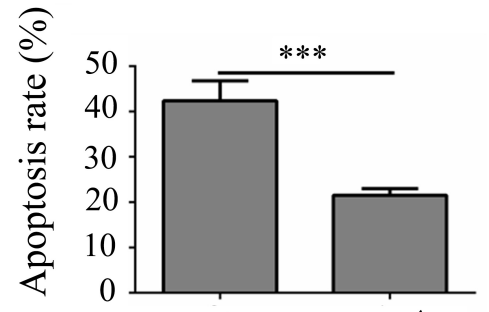

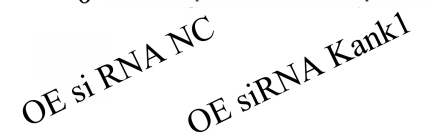

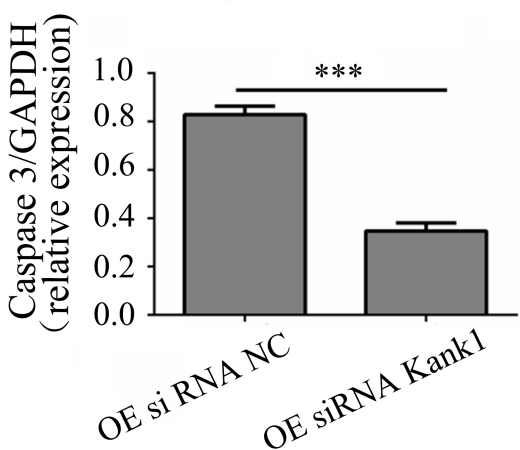

D

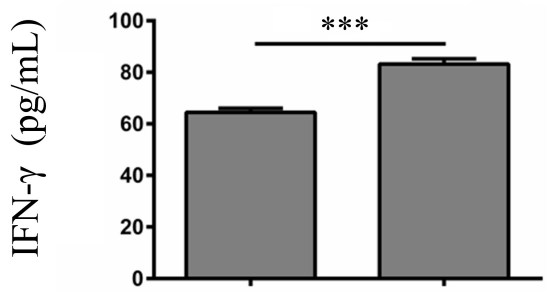

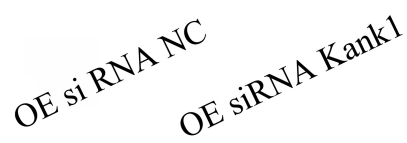

FIGURE 5 | LncRNA-ENST00000421645 promoted apoptosis and inhibited the secretion of IFN- $\gamma$ through Kank1 in T lymphocytes. (A) Apoptosis was detected in OEsiRNA NC cells and OEsiRNA Kank1 cells with a TUNEL apoptosis detection kit. (B) The protein level of caspase3 in OEsiRNA NC cells and OEsiRNA Kank1 cells was determined by Western blot analysis. (C) The relative fold change in IFN- $\gamma$ mRNA expression in OEsiRNA NC cells and OEsiRNA Kank1 cells was determined by RT-qPCR. (D) The IFN- $\gamma$ protein concentration in OEsiRNA NC cells and OEsiRNA Kank1 cells was measured by ELISA (*** $P<0.001)$. Student's $t$-test was used for comparisons between two groups. Two-tailed $P$-values less than 0.05 were considered statistically significant.

Aguilera et al. (2006) reported that 14-3-3 regulates the NF-kB signaling pathway by binding to NF-kB p 65 and IKB $\alpha$. We further investigated whether the upregulated IncRNA-ENST00000421645 in $\mathrm{CD}^{+}$cells of neurosyphilis patients regulates Kank1 and thus plays an important role in 14-3-3 protein expression and NF-kB pathway activation. In this study, after Kank1 gene expression was knocked down in T lymphocytes by siRNA, the 14-3-3 gene and 14-3-3 protein expression levels were significantly decreased and the p-IKBA level was increased in T lymphocytes with Kank1 knockdown. This finding demonstrated that $\ln R$ RNAENST00000421645 promoted 14-3-3 protein expression through Kank1 and then inhibited NF-kB signaling pathway activation, thereby suppressing IFN- $\gamma$ secretion. IFN- $\gamma$ plays an important role in the activation, growth, and differentiation of $\mathrm{T}$ cells and is indispensable for inflammatory and cell-mediated immune responses (Ushio et al., 1996). Interactions between IncRNAs and IFN- $\gamma$ loci control the expression of IFN- $\gamma$. The first lncRNA identified to regulate IFN- $\gamma$ expression was NeST. NeST, with a length of $170 \mathrm{~KB}$, is located downstream of the IFN- $\gamma$ gene and interacts with IFN- $\gamma$ as an anti-sense lncRNA (Vigneau et al., 2003). NeST binds to WDR5 to activate H3K4 and drive methylation to enhance chromatin accessibility, which in turn reduces the recruitment of local histones at nearby IFN- $\gamma$ loci and promotes IFN- $\gamma$ transcription (Vigneau et al., 2003). The IncRNA NRON sequesters NFAT in the cytoplasm, inhibiting it, and inhibits the interaction between NFAT and the IFN- $\gamma$ 


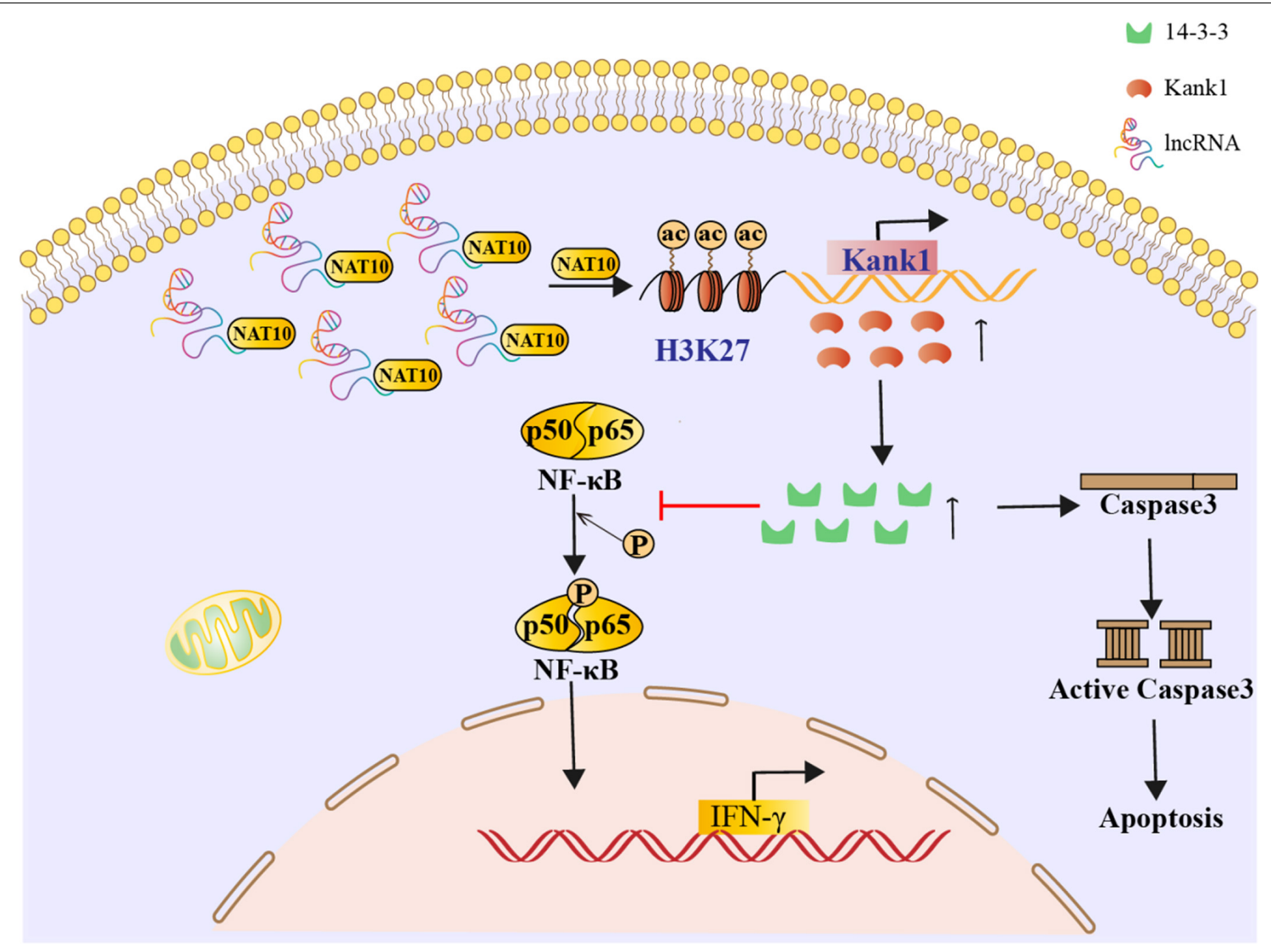

FIGURE 6 | A mechanistic diagram of T lymphocyte regulation by IncRNA-ENST00000421645 was shown.

promoter, thus suppressing the expression of IFN- $\gamma$ (Willingham et al., 2005). The lncRNA SROS1 inhibits the binding of STAT1 mRNA to the RBP CAPRIN1, thereby disrupting STAT1 mRNA stability and thereby inhibiting IFN- $\gamma$-mediated clearance of Listeria monocytogenes from macrophages. As discussed by Willingham et al. (2005) and Booty et al. (2016) when the expression of IFN- $\gamma$ is low, susceptibility to mycobacterial and fungal infections is common. Does low expression of IFN- $\gamma$ also increase susceptibility to TP infection? We speculated that the high expression of $\operatorname{lncRNA}$-ENST00000421645 in T lymphocytes of neurosyphilis patients accelerated the apoptosis of $\mathrm{CD} 4^{+} \mathrm{T}$ cells and thus impaired the immune response of $\mathrm{T}$ lymphocytes. Inhibition of IFN- $\gamma$ expression contributes to the immune escape of $T P$, which survives in the nervous system, eventually leading to the occurrence of neurosyphilis. Interventions that inhibit $\mathrm{T}$ lymphocyte apoptosis and suppress the expression of $\operatorname{lncRNA-}$ ENST00000421645 may constitute a novel therapeutic strategy to reduce the occurrence of neurosyphilis in syphilis patients.

The limitations were that the result of $\operatorname{lncRNA-}$ ENST00000421645 promoting the acetylation of histone $\mathrm{H} 3 \mathrm{~K} 27$ adjacent to the Kank1 promoter would be better if there is a WB map. The underlying mechanism of Kank1 driving the expression of 14-3-3 is not clear and requires further studies. However, this study filled in the knowledge gap regarding

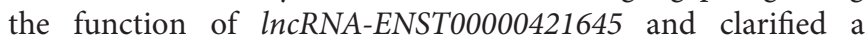

new mechanism of the transcriptional regulation of IFN- $\gamma$ by IncRNA-ENST00000421645.

\section{DATA AVAILABILITY STATEMENT}

The original contributions presented in the study are included in the article/supplementary material, further inquiries can be directed to the corresponding author/s.

\section{ETHICS STATEMENT}

The studies involving human participants were reviewed and approved by the Ethics Committee of Zhongshan Hospital and was in accordance with the Helsinki Declaration. The patients/participants provided their written informed consent to participate in this study.

\section{AUTHOR CONTRIBUTIONS}

K-XW, X-TW, and L-LL conceived and designed the experiments. K-XW, X-TW, and M-LT performed the 
experiments. X-LH, X-YJ, and J-CZ analyzed the data. Y-ZX, L-RL, and T-CY contributed reagents, materials, and analysis tools. K-XW and L-LL wrote the manuscript. All authors contributed to the article and approved the submitted version.

\section{FUNDING}

This work was supported by the National Natural Science Foundation of China (grant nos. 81971147, 81771312, 81471231, 81101324, 81972028, and 81973104) and the Xiamen Science and

\section{REFERENCES}

Aguilera, C., Fernández-Majada, V., Inglés-Esteve, J., Rodilla, V., Bigas, A., and Espinosa, L. (2006). Efficient nuclear export of p65-IkappaBalpha complexes requires 14-3-3 proteins. J. Cell Sci. 119(Pt 17), 3695-3704. doi: 10.1242/jcs. 03086

Booty, M. G., Nunes-Alves, C., Carpenter, S. M., Jayaraman, P., and Behar, S. M. (2016). Multiple Inflammatory Cytokines Converge To Regulate CD8+ T Cell Expansion and Function during Tuberculosis. J. Immunol. 196, 1822-1831. doi: $10.4049 /$ jimmunol.1502206

Chong, L. (2001). Molecular cloning - A laboratory manual. Science 292:446. doi: $10.1126 /$ science. 1060677

Gonzalez, H., Koralnik, I. J., and Marra, C. M. (2019). Neurosyphilis. Semin. Neurol. 39, 448-455. doi: 10.1055/s-0039-1688942

Jiang, M., Zhang, S., Yang, Z., Lin, H., Zhu, J., Liu, L., et al. (2018). Self-Recognition of an Inducible Host IncRNA by RIG-I Feedback Restricts Innate Immune Response. Cell 173, 906.e-919.e. doi: 10.1016/j.cell.2018.03.064

Jou, Y. C., Wang, S. C., Dai, Y. C., Chen, S. Y., Shen, C. H., Lee, Y. R., et al. (2019). Gene expression and DNA methylation regulation of arsenic in mouse bladder tissues and in human urothelial cells. Oncol. Rep. 42, 1005-1016. doi: 10.3892/or.2019.7235

Kakinuma, N., Roy, B. C., Zhu, Y., Wang, Y., and Kiyama, R. (2008). Kank regulates RhoA-dependent formation of actin stress fibers and cell migration via 14-3-3 in PI3K-Akt signaling. J. Cell Biol. 181, 537-549. doi: 10.1083/jcb.200707022

Leader, B. T., Godornes, C., VanVoorhis, W. C., and Lukehart, S. A. (2007). CD4+ lymphocytes and gamma interferon predominate in local immune responses in early experimental syphilis. Infect. Immun. 75, 3021-3026. doi: 10.1128/iai. 01973-06

Li, J., Chen, C., Ma, X., Geng, G., Liu, B., and Zhang, Y. (2016). Long noncoding RNA NRON contributes to HIV-1 latency by specifically inducing tat protein degradation. Nat. Commun. 7:11730. doi: 10.1038/ncomms11730

Li, K., Wang, C., Lu, H., Gu, X., Guan, Z., and Zhou, P. (2013). Regulatory T cells in peripheral blood and cerebrospinal fluid of syphilis patients with and without neurological involvement. PLoS Negl. Trop Dis. 7:e2528. doi: 10.1371/journal. pntd.0002528

Li, P., Nijhawan, D., Budihardjo, I., Srinivasula, S. M., Ahmad, M., Alnemri, E. S., et al. (1997). Cytochrome c and dATP-dependent formation of Apaf1/caspase-9 complex initiates an apoptotic protease cascade. Cell 91, 479-489. doi: 10.1016/s0092-8674(00)80434-1

Liu, L. L., Chao, P. L., Zhang, H. L., Tong, M. L., Liu, G. L., Lin, L. R., et al. (2013). Analysis of lymphocyte subsets in HIV-negative neurosyphilis patients. Diagn. Microbiol. Infect. Dis. 75, 165-168. doi: 10.1016/j.diagmicrobio.2012.10. 007

Liu, L. L., Zhu, S. G., Jiang, X. Y., Ren, J., Lin, Y., Zhang, N. N., et al. (2017). LncRNA Expression in CD4+ T Cells in Neurosyphilis Patients. Front Cell Infect. Microbiol. 7:461. doi: 10.3389/fcimb.2017.00461

Liu, W., Huang, L., Wei, Q., Zhang, Y., Zhang, S., Zhang, W., et al. (2018). Microarray analysis of long non-coding RNA expression profiles uncovers a Toxoplasma-induced negative regulation of host immune signaling. Parasit. Vectors 11:174. doi: 10.1186/s13071-018-2697-8
Technology Planning Project (Grant No. 3502Z20209032). The funders played no role in the study design, data collection or analyses, the decision to publish, or manuscript preparation.

\section{ACKNOWLEDGMENTS}

We would like to thank the two groups of patients for their participation in this study, as well as the doctors from Zhongshan Hospital affiliated to Xiamen University who identified the patients and referred them to our study.

Liu, X., Zhou, F., Wang, W., Chen, G., Zhang, Q., Lv, R., et al. (2021). IL-9triggered lncRNA Gm13568 regulates Notch1 in astrocytes through interaction with CBP/P300: contribute to the pathogenesis of experimental autoimmune encephalomyelitis. J. Neuroinflammation 18:108. doi: 10.1186/s12974-02102156-5

Livak, K. J., and Schmittgen, T. D. (2001). Analysis of relative gene expression data using real-time quantitative PCR and the 2(-Delta Delta C(T)) Method. Methods 25, 402-408. doi: 10.1006/meth.2001.1262

Marra, C. M., Castro, C. D., Kuller, L., Dukes, A. C., Centurion-Lara, A., Morton, W. R., et al. (1998). Mechanisms of clearance of Treponema pallidum from the CSF in a nonhuman primate model. Neurology 51, 957-961. doi: 10.1212/wnl. 51.4.957

Nance, D. J., Satterwhite, E. R., Bhaskar, B., Misra, S., Carraway, K. R., and Mansfield, K. D. (2020). Characterization of METTL16 as a cytoplasmic RNA binding protein. PLoS One 15:e227647. doi: 10.1371/journal.pone.0227647

Porter, A. G., and Jänicke, R. U. (1999). Emerging roles of caspase-3 in apoptosis. Cell Death Differ 6, 99-104. doi: 10.1038/sj.cdd.4400476

Schmitt, A. M., and Chang, H. Y. (2016). Long Noncoding RNAs in Cancer Pathways. Cancer Cell 29, 452-463. doi: 10.1016/j.ccell.2016.03.010

Soleimani, M., and Sajedi, N. (2020). Myricetin Apoptotic Effects on T47D Breast Cancer Cells is a P53-Independent Approach. Asian Pac. J. Cancer Prev. 21, 3697-3704. doi: 10.31557/apjcp.2020.21.12.3697

Ushio, S., Namba, M., Okura, T., Hattori, K., Nukada, Y., Akita, K., et al. (1996). Cloning of the cDNA for human IFN-gamma-inducing factor, expression in Escherichia coli, and studies on the biologic activities of the protein. J. Immunol. 156, 4274-4279.

Vigneau, S., Rohrlich, P. S., Brahic, M., and Bureau, J. F. (2003). Tmevpg1, a candidate gene for the control of Theiler's virus persistence, could be implicated in the regulation of gamma interferon. J. Virol. 77, 5632-5638. doi: 10.1128/jvi. 77.10.5632-5638.2003

Wang, N., Yu, Y., Xu, B., Zhang, M., Li, Q., and Miao, L. (2019). Pivotal prognostic and diagnostic role of the long non-coding RNA colon cancer-associated transcript 1 expression in human cancer (Review). Mol. Med. Rep. 19, 771-782. doi: 10.3892/mmr.2018.9721

Wang, Y., Zhang, X., Chen, W., Gao, L., Li, J., Song, T., et al. (2020). Cortistatin ameliorates Ang II-induced proliferation of vascular smooth muscle cells by inhibiting autophagy through SSTR3 and SSTR5. Life Sci. 253:117726. doi: 10.1016/j.lfs.2020.117726

Wang, Y., Zhong, H., Xie, X., Chen, C. Y., Huang, D., Shen, L., et al. (2015). Long noncoding RNA derived from CD244 signaling epigenetically controls CD8+ T-cell immune responses in tuberculosis infection. Proc. Natl. Acad. Sci. U S A 112, E3883-E3892. doi: 10.1073/pnas.1501662112

Willingham, A. T., Orth, A. P., Batalov, S., Peters, E. C., Wen, B. G., Aza-Blanc, P., et al. (2005). A strategy for probing the function of noncoding RNAs finds a repressor of NFAT. Science 309, 1570-1573. doi: 10.1126/science.1115901

Winstel, V., Schneewind, O., and Missiakas, D. (2019). Staphylococcus aureus Exploits the Host Apoptotic Pathway To Persist during Infection. mBio 10:6. doi: 10.1128/mBio.02270-19

Xie, S. C., Yang, Y. J., Zhang, J. Q., Zhou, S., Xie, S. W., and Hua, Y. Y. (2019). HOXD-AS1: a novel oncogenic long intergenic non-coding RNA in humans. 
Eur. Rev. Med. Pharmacol. Sci. 23, 2898-2907. doi: 10.26355/eurrev_201904_ 17568

Yang, X., Bam, M., Becker, W., Nagarkatti, P. S., and Nagarkatti, M. (2020). Long Noncoding RNA AW112010 Promotes the Differentiation of Inflammatory $\mathrm{T}$ Cells by Suppressing IL-10 Expression through Histone Demethylation. J. Immunol. 205, 987-993. doi: 10.4049/jimmunol.200 0330

Yao, Y., Jiang, Q., Jiang, L., Wu, J., Zhang, Q., Wang, J., et al. (2016). LncSGK1 induced by Helicobacter. Oncotarget 2016, 20549-20560. doi: 10.18632/ oncotarget.7823

Yılmaz Susluer, S., Kayabasi, C., Ozmen Yelken, B., Asik, A., Celik, D., Balci Okcanoglu, T., et al. (2018). Analysis of long non-coding RNA (lncRNA) expression in hepatitis B patients. Bosn. J. Basic Med. Sci. 18, 150-161. doi: 10.17305/bjbms.2018.2800

Yin, Z., Guan, D., Fan, Q., Su, J., Zheng, W., Ma, W., et al. (2013). IncRNA expression signatures in response to enterovirus 71 infection. Biochem. Biophys. Res. Commun. 430, 629-633. doi: 10.1016/j.bbrc.2012.11.101
Conflict of Interest: The authors declare that the research was conducted in the absence of any commercial or financial relationships that could be construed as a potential conflict of interest.

Publisher's Note: All claims expressed in this article are solely those of the authors and do not necessarily represent those of their affiliated organizations, or those of the publisher, the editors and the reviewers. Any product that may be evaluated in this article, or claim that may be made by its manufacturer, is not guaranteed or endorsed by the publisher.

Copyright (C) $2021 \mathrm{Wu}$, Wang, Hu, Jiang, Zhuang, Xu, Lin, Tong, Yang and Liu. This is an open-access article distributed under the terms of the Creative Commons Attribution License (CC BY). The use, distribution or reproduction in other forums is permitted, provided the original author(s) and the copyright owner(s) are credited and that the original publication in this journal is cited, in accordance with accepted academic practice. No use, distribution or reproduction is permitted which does not comply with these terms. 